This item is the archived peer-reviewed author-version of:

Dirty things: spiritual pollution and life after the Lords Resistance Army

\title{
Reference:
}

Victor Letha, Porter Holly.- Dirty things: spiritual pollution and life after the Lords Resistance Army

Journal of eastern African studies - ISSN 1753-1063 - 11:4(2017), p. 590-608

Full text (Publisher's DOI): https://doi.org/10.1080/17531055.2017.1373441

To cite this reference: https://hdl.handle.net/10067/1568670151162165141 


\section{Dirty things: spiritual pollution and life after the Lord's Resistance Army}

Letha Victor and Holly Porter

\section{ABSTRACT}

In post-war northern Uganda (as elsewhere), the reintegration of excombatants into their home communities is an ongoing process that involves long-term social and spiritual labour. The "re" of "reintegration," however, might falsely assume a static and cohesive Acholi cosmology within which the parameters of such labours are clearly defined. Pathways taken with the goal of lessening suffering caused by war are tread by Acholi civilians and ex-combatants alike, and the ways former Lord's Resistance Army (LRA) fighters attempt to alleviate spiritual distress illuminate wider struggles for moral authority in everyday life. These practices are embedded in cosmologies which, though predating the 20 years of violent upheaval that ended in 2006, are sites of contestation where the politics of belief and doubt are played out. Drawing on insights gleaned from ethnographic fieldwork over the last decade, we focus here on targeted research from January to August 2014 with former LRA individuals who were part of a bigger study of clients at an ex-combatant reception centre. We explore how these persons have experienced, described, and responded to the suffering caused by ajwani ("dirty things") - the stuff of a polluted cosmos. We further discuss the politics of "belief" and doubt in contemporary Acholi. The labour of excombatants and their communities to alleviate spiritual suffering demonstrates how ritual practices both challenge and uphold the power of moral authorities. In the wider context of post-war sociality in Acholi, effective and socially acceptable alleviation of spiritual suffering is contested, processual, and highly constrained by material resources and perceptions of ritual legitimacy. The practices of belief and doubt are not only a matter of metaphysics or ontology, but of shifts in worldly power.

I tried getting saved, but it didn't work. (Lucy) ${ }^{1}$

Lucy was at home, sorting peas, when fighters in the Lord's Resistance Army (LRA) abducted her and marched her across the border into (what was then) southern Sudan. After two years of coerced soldiering and a forced relationship that produced a son, in 1999 she escaped only to be arrested by a group of Sudanese soldiers. She was forced into another relationship that lasted nearly 10 years and resulted in two more children. A chance meeting of Ugandan traders in a market provided her the opportunity to flee South Sudan with her younger children, but hasty circumstances forced her to leave her eldest behind. Back in Uganda, she and her children were received by Gulu Support the Children Organization (GUSCO), a reception centre for former LRA. At GUSCO, Lucy and her children were fed, housed, clothed, provided with medical care, and reunited with her family. She had been away 13 years. Since returning, she has begun a home with a new husband and they have had three children together. She makes a modest living through farming and selling charcoal.

Shortly after she returned to her home village, Lucy began to suffer from what she suspected were spiritual attacks: often, she saw the apparition of a man in front of her and another behind, and she felt trapped. Other times the figures would peer through the windows of her house. "I don't see their faces well," she said. When the spectres appeared, she would scream for her husband, who came running but found no one there. In her terror, she sometimes dropped or threw her children. Yet she was not certain if the attacking force was cen, the angry spirit of someone who has died a bad death, or some other unseen force. She only knew some "dirty thing," (ajwani) was afflicting her. 
Lucy's parents had died and her husband and his relatives have not yet made customary payments formalizing their relationship. Thus by convention her elder brother is responsible for her. He took her to a spirit-medium and healer (ajwaka), saying: "Sickness is there" (Twoo tye).

The ajwaka summoned the divinatory spirits who aid her. Through her they questioned Lucy and determined that she was haunted by cen, the vengeful spirits of people she saw killed while in the LRA. The ajwaka explained the spirits had attached themselves to her because she was "too kind" in the bush. ${ }^{2}$ The ajwaka made a list of items (goats, chicken, clothing, beans, rice, and an honorarium for her services) needed to chase them away. However, the cost was prohibitive for Lucy and her family and they looked for other means of redress.

Her husband suggested she get "saved" at a local Pentecostal church. "I had no money, and at least getting saved is free," she recalled. A pastor came to her home and told her what it means to be "born again." The rules, she explained, are that you should not drink alcohol, quarrel, or abuse others. Her husband told the "born-agains" of her problems. They did not call Lucy's ajwani "cen," but instead "satans" or "demons" that could only be eliminated through prayer. But the prayers, she lamented, "didn't work." The ajwani continued to torment her.

This article examines the social and spiritual labour of ex-LRA combatants who, like Lucy, express distress through the idiom of "dirty things" (ajwani). The Acholi concept of ajwani, described below, provides a window into the phenomenon of cosmological pollution: an imbalance in the moral community of human and non-human spirits, living and dead. We argue that interpretations of ajwani do not only apply to ontological propositions (whether cen is "real" or not, for example). Rather, our interlocutors' attempts to relieve their suffering signal trust in those with ritual and moral power.

In describing the challenges faced by ex-combatants, their families and communities, to find effective, moral, and socially acceptable solutions to the problem of ajwani, we place their lived experiences of cosmological (dis)repair within the wider context of post-war social change. Where others have made important interventions to the study of social repair in post-war and postdisplacement northern Uganda, ${ }^{3}$ here we aim to contribute to the discussion of reintegration - as well as social rupture - by complicating the role of cosmology. In approaching cosmology as culturally-shared understandings of forces in the universe (sacred and profane), our intervention concerns the problem of ex-combatant reintegration lived within a dynamic worldview inhabited by seen and unseen purposive powers that permeate the cosmos. Erin Baines, in her insightful 2010 article on spirits and social reconstruction in northern Uganda, argues that spirit possession phenomena and ritual cleansing practices are "expressions of injustice and reflect people's attempts to seek moral renewal and social repair." ${ }^{4}$ This is an important intervention in the transitional justice literature. A concern with interpreting such phenomena through the lens of (in)justice, however, is the ways this vision might be instrumentalized for particular political or normative agendas. In contrast, we find our interlocutors understandings and experiences of "Acholi spirit worlds" to be much more contested, diverse, and dynamic than a traditional/local vs. Christian/Muslim dichotomy would suggest. Rather than focusing on how spirit phenomena reflect (in)justice, we focus on the wider concept of pollution that predates (but has been made acute by) contemporary political violence.

Our observations are rooted in our respective ethnographic fieldwork in the Acholi sub-region over the last decade, but also draw specifically on research conducted by the authors and by the Justice and Security Research Programme (JSRP) research team over the course of 2013 and 2014 with exLRA who were former clients of GUSCO, a reception centre for ex-combatants. This article centres 
around further research with the GUSCO clients we identified from this group who like Lucy, described experiencing spiritual distress. We explore how those ex-combatants and those around them have interpreted and responded to these experiences.

We take a basic phenomenological approach to the problems experienced by our informants inasmuch as we are less concerned with the empirical status of ajwani than the lived experiences of those who are affected by them. We strive to take things "as they are." ${ }^{5}$ We ask how ajwani work as social realities in Acholi, and posit that our respondents do not experience all spiritual phenomena as supernatural, but as arising from both ordinary and extraordinary events, local histories, and social processes. We take our informants' interpretations seriously and additionally avoid the temptation to equate social and spiritual torment with individualized medical pathology, ${ }^{6}$ including making lay diagnoses of "trauma." While many psychological and psychosocial services are undoubtedly appropriate and valuable in some instances (and such services are lacking in northern Uganda), we are cognizant that they are culturally bound and entangled in particular medical, colonial, military, and political histories. ${ }^{7}$ Thus, we engage the socio-spiritual experiences of excombatants not as instruments to a taxonomy of illness, disease, and therapy, but as phenomena to be understood in and of themselves.

Our contribution is threefold. Firstly, we present new ethnographic data on the lived experiences of ex-LRA returnees, 10 years after the war effectively ended within northern Uganda. We find that suffering caused by ajwani has the potential to instigate not only the subjective transformations of individual persons, but that it is intertwined with contested social transformation. Secondly, we explore the politics of "belief" and doubt and how they are tied to the pursuit of and experience of alleviating suffering. Finally, we contend that responses to the pollution of ajwani pivot around issues of ritual and moral authority. In the wider context of post-war Acholi sociality, effective and socially acceptable alleviation of spiritual suffering is contested, processual, and highly constrained not only by material resources, but by the perceived power and legitimacy of cosmological experts. In order to understand the backdrop in which these experiences are lived we provide some background on the context in the Acholi sub-region of northern Uganda as well as our approach to the study.

\section{Context}

The LRA is infamous for the abduction of civilians to acquire new "recruits," particularly children. Although not a tactic unique to the LRA, between 1986 and 2006 they abducted an estimated 66,000 Ugandans, ${ }^{8}$ while between 2008-2011 the LRA abducted over 3,000 individuals in the Democratic Republic of Congo, the Central African Republic, and South Sudan. ${ }^{9}$ Once in the LRA, new members were initiated into a variety of roles: soldiers, porters, spies, baby-sitters, cooks, and more. Girls and women were commonly distributed as "wives" to senior commanders, and many had children as a result. $^{10}$

Moreover, in 1996 the Government of Uganda began relocating residents (often forcibly) into poorly protected and under-equipped internally displaced persons (IDP) camps. In addition to squalid conditions, food shortages, and frequent raids by the LRA, an entire generation of Acholi youth was raised in the camps. Daily life was interrupted and changed in dramatic ways, and as a result the more common methods of intergenerational cultural transition and moral education were undermined. ${ }^{12}$ While IDP camps have since closed and most people have resettled, many social effects continue.

Although at the time of writing the LRA continues to operate within nearby central African countries and the Final Peace Agreement (negotiated with the Government of Uganda between 2006-2008) 
was never signed, northern Uganda has enjoyed relative peace since 2006. LRA returnees continue to trickle in to GUSCO.

Several in-depth reports on LRA abductees' experiences, especially those formally received by reception centres in Gulu, have been published, particularly in the years following their return. ${ }^{13}$ These reports provide key evidence about the experiences of LRA recruits, both during their time in the bush and immediately after return. However, little is known about the wellbeing of formerly abducted persons years after their homecomings.

In response to this, between October 2012 and March 2013 the JSRP interviewed 234 former GUSCO clients. ${ }^{14}$ These interviews included a series of open-ended questions about life in the LRA, immediate and long-term experiences of return to civilian life, and their current situations and relationships, as well as participation in ritual and prayer, discussed below. ${ }^{15}$ This article is based on our analysis of this data as well as our further ethnographic work (from January to August 2014) with individuals we identified from that sample as self-reporting spiritual disturbances (broadly defined). These interlocutors included men and women who pursued various resolutions to their problems, with assorted degrees of success (by their own estimations). We conducted initial formal follow-up interviews with the aforementioned, but our interpretations here are primarily ethnographic: we interacted with these former GUSCO clients over time, observing and conversing with their families, and also the persons involved in their various processes of seeking explanations and remedies for maladies. These included ajwaki, pastors, clan elders, school administrators, neighbours, and relatives). ${ }^{16}$

\section{Spiritual pollution}

Ajwani, as a broadly applied term for cosmological upset, are the "dirty things" (as we were told in English) often instantiated by gross misfortune or the presence of rancorous spirit forces. Pollution may be caused by a variety of things: by the breaking of taboos or contraventions in normative behaviour. Returning to Lucy, the young woman whose story we began with, the spirit-medium and healer who attended to her determined that she was haunted by a common form of ajwani known as cen. Cen can bring sickness, debilitating daytime visions and nightmares, gross misfortune, madness, and even death, and is feared as a social contagion.

The Italian missionary Father J.P. Crazzolara interpreted cen as "a departed spirit, vengefully disposed,"17 while Okot p'Bitek, himself a native of Gulu Town, translated it as "ghostly vengeance." 18 More recently, Finnström has defined cen as the "spirits of people who died violently," ${ }^{19}$ while others have noted its character as a social pollutant and therefore communal problem. ${ }^{20} \mathrm{~A}$ person may provoke cen by perpetrating or witnessing a violent or otherwise bad death, by desecrating a corpse, or, as was common among our informants, by stepping on or over exposed human remains. ${ }^{21} \mathrm{An}$ individual forced to kill another, a person who willingly participates in a murder, or a stranger who stumbles upon bones - regardless of their intentions - might rile a vengeful spirit.

In the GUSCO sample $(n=234), 19 \%$ percent of males complained of having experienced cen, while the number was just over $27 \%$ for females. Combined, $22 \%$ of the sample reported experiencing cen at some point since return from the LRA, while nearly $46 \%$ reported experiencing nightmares or flashbacks related to their time in captivity. However, most respondents firmly distinguished cen as an affliction distinct from, though often accompanied by, nightmares and flashbacks. Spiritual upsets like cen are not easily defined and their causes are not simply determined: uncertainty complicates the task of cleansing spiritual pollution. 
Cen has received much scholarly attention, particularly as pertaining to ex-combatants, as the opportunities for the above described trespasses of moral order were very common "in the bush." As such cen has, however imprecisely, become a kind of shorthand for all spiritual malady, particularly for those in the remit of the NGO and reintegration industry in northern Uganda. ${ }^{22}$ Some of our interlocutors speak openly of being affected by cen, with those closest to them confirming those interpretations. But they also speak of ajwani in general, or other specific pollutants apart from cen such as ajiji (a bad memory that haunts one's thoughts), tipu dano (the spirits of people living or deceased), jok (pl. jogi; naturally occurring spirits ${ }^{23}$ ), ayweya (spirits usually connected to features in the environment such as big trees rocks or water points), kwaro (ancestors), demons, devils, and Satan or "Satans." 24 The way they designate and define these rely less on typological precision and more on identifying categories that help the pursuit of remedy.

Another concept in Acholi cosmology that indicates pollution or ajwani is kiir, usually translated as "abomination" or "curse." It is akin to taboo-breaking, and can result in dangerous spiritual pollution. ${ }^{25}$ Kiir is a transgression of the moral order that encompasses actions as wide-ranging as murder, mishandling corpses, neglecting to perform proper burial rites, fighting in the garden or at water sources, having sex in the wilderness, burning down houses, throwing food or money in anger, or cursing one's offspring by pointing one's bare breasts or penis in their direction. "Dirty things" resultant from kiir can disrupt the well-being of entire families by imparting misfortune and sickness not only to individual taboo-breakers, but their children and others in close social proximity. Pollution thus disrupts sociality and signifies that a moral breach has occurred and needs redressing.

Like any other concept signified by language, ajwani does not mean the same thing at all times to all people, nor is it the exclusive term by which our informants identify distress. In fact, the most common words people used to describe their experiences (in Acholi and English) were grammatical demonstratives: it, they, that thing, or those things. Our respondents often mentioned that "these things move together" and that, without expertise, it is difficult to distinguish between types of ajwani, to determine how many spirits possess one person, or to establish capricious spirits' intentions. As such, to name or "diagnose" and act upon spiritual affliction is a process embroiled in the politics of "belief," doubt, and claims of ritual expertise.

In Acholi, knowledge of a spiritual being or phenomenon does not necessarily equate to "belief," acceptance, or faith in it. Many scholars have established that it is intellectually perilous to assume a shared concept of "belief" across linguistic and epistemic divides, yet secular (or post-Christian) societies and their scholars (shaped by the language and social history of protestantism) often conflate the concepts of belief and existence. ${ }^{26}$ Recently, Nils Bubandt has called for an analytic "suspension of belief" in witchcraft studies, arguing that it is doubt and aporia (rather than certainty) that is witchcraft's primary condition. ${ }^{27}$ In a similar vein, dirty things are tied to uncertain possibilities that nonetheless require action. In relation to the lived experiences of our informants, the Acholi word "geno," which might be translated as "belief," connotes aspects of faith, hope, and trust. Two other words are relevant and often used together: "tye" which signifies existence and "yee" which is sometimes translated as "belief" and points to agreement, obedience or assent. Consequently, it is not uncommon to hear a native-Acholi speaker say in English, "Cenis there, but I don't believe in it." In Acholi, people often say: "Cen tye ento pe ageno," or, as we would interpret this, "Cen exists, but I do not put any trust in it." How, then, to respond to pollution in the cosmos?

\section{The politics of belief and doubt}

When unfortunate events suspected to have meta-physical dimensions occur, those involved often conduct an investigation into possible explanations and thus appropriate responses. For example, school children who collapsed in fits, though they were thought likely to be possessed by some dirty 
thing, in the first, instance were taken to the local Health Centre for examination. With all tests negative, and no causes found, parents and teachers sought another explanation: an imbalance or pollution in the spirit world, needing identification and correction. Like Evans-Pritchard's example of a collapsed granary (understood by Azande as the simultaneous result of both witchcraft and termites),28 multiple explanations often co-exist. When preparing for the burial of a loved one and discussing the cause of death (which the coroner report determined was "natural"), someone remarked: "There is no natural death." ${ }^{29}$ Such statements indicate not just a search for explanations, but an understanding of cosmological ordering.

Since a variety of ajwani may be culprits of malady, specialists are often called upon to "diagnose" and prescribe a remedy. Distinctions between types of ajwani are important insofar as they may indicate why they are being troublesome and whether they should be appeased or "chased" (ryemo) through ritual sacrifices (tum) or through prayer and faith (geno) in Jesus. In some instances ajwani are exorcized, in other cases it is deemed appropriate that spirits be socialized and propitiated.

These approaches may be used simultaneously or exclusively, depending on the wishes of the family, though tension often arises between individuals and groups over which approach is considered most moral and effective. As Allen notes, consensus that spiritual pollutants have been effectively contained sometimes requires a combination of methods. ${ }^{30}$ Many Acholi Anglicans and Catholics find (at least some) aspects of tic Acholi (Acholi work or ritual) commensurable with Christian worship. Conversely, "born again" or charismatic contingents of all Christian sects widely regard so-called "cultural" rituals and sacrifices as inherently evil. Despite moral disagreement over these forms of ritual work, they share common characteristics: sacrifice, sociality (each of these rituals is a social gathering that offers opportunities for support and recognition amongst kin and non-kin), and even the exertion of newfound power. Below the stories of three of our excombatant informants are explored. Together they highlight common dynamics in the politics of belief, doubt, and the practical and ethical challenges in pursuit of remedies for spiritual pollution.

\section{Lucy}

Some months after her brother took her for an initial consultation with the ajwaka, a group of filmmakers offered to fund the ritual in exchange for allowing them to document it. The family agreed and arrangements were made for the ajwaka and her assistants (singers) to come to their home. The process was lengthy and unpredictable. It began around sunset and those attending (including the second author) did not leave until two days later. Most of Lucy's time was spent in a cleanly swept and emptied hut, where the ajwaka sat in a corner, her head covered with a sheet when the spirits spoke through her. The singers, as well as Lucy's relatives and friends, were crowded on the floor, and one sitting mat was placed in the centre for Lucy. Surrounded by people whose presence was oriented around her alone, Lucy danced beautifully. The singers sung and drums were played late into the night. As a woman who had to beg from her brother and in-laws, now she could suddenly be generous: "The spirits want alcohol to be given to the singers," she said, and it was done. If she wanted to eat, drink, sing, rest - she said the word and it was done.

The ajwaka determined that Lucy had three different types of spirits: ayweya, cen, and jogi. As mentioned above, ayweya and cen are malevolent and need to be chased away by sacrifice. On the second day three goats and one chicken were tumu - cut, or sacrificed, ${ }^{31}$ with Lucy running with each of the animals (in turn) out of the homestead and into the bush where they were killed, then cooked and eaten there by all the attendants.

The jogi, however, did not need to be chased away. While jogi are volatile spirits, for many Acholi they are not considered inherently malevolent. They are powerful and are to be revered. If "well- 
maintained" (e.g. by being fed or having other demands regularly met), they can become a source of new power for their custodian. A jok may assist in matters of divination and healing, for example, during Lucy's ceremony the jogi announced they wished her to become an ajwaka. In this way, possession by spirits can lead to the birth of a healer. ${ }^{32}$

She and her family agreed she would become an ajwaka, in part because she might prove helpful to those around her as well as earn income. Once the initiation ceremony is done, she will have gone from a haunted and destitute woman, constantly on the receiving end of charity and dependent upon men in her life, to a possessor of spiritual powers, able to heal others and contribute financially to her family. As a symbol of rebirth, when she is initiated as an ajwaka, a requirement is that "all things should be like new," and she will be given new clothes, new bedsheets, and new kitchen utensils.

\section{Proscovia}

Proscovia was abducted when she was 12 years old and spent seven years in the LRA before escaping and returning to civilian life. Her mother was killed by the LRA in the interim, and her father had turned to alcohol. Shortly after she returned home, spirits began affecting her. At times she became disoriented, removing her clothes and wandering aimlessly. "I would start talking and I didn't know what I was saying, but others would tell me later that I used to ask in a different voice: 'Why did you kill me? Why did you hurt me?"” Other times she was conscious of the attack: "It felt like something fell on me and strangled me," she said. "It" would ask her the same haunting questions. Her father was unable to cope with her behaviour and her stepmother rejected her, kicking her out of the family home and calling her a killer. According to her stepmother, Proscovia's behaviour indicated cen, and she did not want such a volatile element in the home. So Proscovia and her children left the village and moved to Gulu.

Proscovia recalls the first time she was forced to kill, not long after she was abducted and, in her own estimation, the spirits who attack her are those she killed in the bush. "We [her close social network] assume those are the people who speak through me," she explained. At times during these attacks she sees her victims or the apparition of a late friend and co-fighter. She sees the friend being tortured and tries to embrace her, to protect her and comfort her, but is unable to reach her. When these visions began disturbing her, Proscovia's neighbours and landlord in town contacted her brother and had him return her to their village, where a ritual tum was performed. A sheep was slaughtered and died while she held it. Elders told her she had been suffering from cen, but that when the sheep died the spirits possessing her left her body and passed into the sheep.

Despite the ritual, cen returned to haunt Proscovia. When she participated in a mass nyono tong gweno ("stepping on an egg," an Acholi homecoming and cleansing ritual after a long absence) organized by the Paramount Chief in Gulu Town, she noted that despite initially finding comfort from stepping on the egg, cen again attacked her with virulence. Over the years she visited numerous ajwaki and tried various tic Acholi, but nothing had a lasting impact. Eventually her husband left her, citing cen as the principle cause. A friend brought her to a Pentecostal church and began praying with her. She found solace in the church community, and for years now a pastor and fellow church members have prayed weekly at her house.

Although the attacks from cen have subsided, social challenges have persisted. When her rented house was burned to the ground, one of her daughters was caught inside and the roof collapsed. She survived with injuries, but the recent harvest Proscovia had stored perished. Another daughter was allegedly poisoned while at school, hospitalized for months, and still suffers health problems. It was Proscovia's new church companions who helped her find a new home and pay for her children's 
medical care. The Local Councillor I (or village level elected leader) refused to help her, saying: "You used to burn the houses of people [while in the LRA] and now that it happens to you, you turn to report it? We will not help." Although she cannot be certain who set the fire or poisoned the food, she feels "no love" outside of the church.

\section{Leo}

Leo was abducted and spent only two months in the LRA, though as he states, his "work was terrible" during that time and he participated in many violent acts. He escaped and was resettled by GUSCO in his home village. While he was a child his father was a respected head teacher, but during the course of the war his father "lost his mind," and became "a drunkard." His father began to increasingly "misbehave," as he described it, and responsibility for family and land management fell to Leo and his brothers. In 2010, eight years after escaping the LRA, a land dispute erupted between his homestead and neighbouring clansmen. Leo suspects they look down upon him because of his participation in the LRA, and wish to take advantage of the incapacity of his father and paternal uncles.

It was during this time he first awoke at night, shivering with cold, struggling to breathe and feeling like he might die. The experience was unlike the nightmares that he periodically suffers: "At least with nightmares, you wake up." Even though conscious, he described how he lost sense in his body. He pinched himself but felt nothing. He could not be shaken from this terror. He bolted out of the house and ran frantically around his homestead until eventually the attack dissipated. Similar attacks continued to occur sporadically, sometimes weekly. His wife would try to keep him inside by locking the door to their house and comforting him. He went to a health centre, but they had no helpful diagnosis and sent him home with paracetamol.

Leo is unsure of the cause of these attacks, or how to respond to them. Guessing at the causes, he said he saw bad things when he was abducted, and was forced to participate in murdering a school classmate. His mother once told him she suspected ajwani resulted from his time in the bush. Yet Leo is equally troubled by the stresses of daily life, and he quickly asserted the nightmares of being chased by soldiers are nothing like his waking panic, which, in his own opinion, are unrelated. He says he cannot determine the causes of these things by himself. He "needs people who have the knowledge to differentiate between sickness and cen." These distinctions were important to him insofar as they would help him pursue an appropriate remedy. Leo felt it was useless to again seek care from the local health centre, but the costs of more adequate medical services are prohibitive.

For Leo's family, acquiring the services of a local healer is not an option, even though this did not seem to stem from some of the commonly expressed Christian objections. "I'm afraid of going to an ajwaka," he said, "And entering into all those dirty things." His mother had made a promise to her late father never to work with ajwaki, and Leo himself fears what he deems their "black, dirty work" considering it to be a source of death. There are other rituals, led by elders, not based on the works of ajwaki (as are some of those related above), but these still require specialist knowledge. We asked him about these as well but, he explained, "I can't say much because if I look at the history of my family these things weren't there. I never saw the process of chasing cen, kulu [a water spirit] or ayweya. I think we never did those things in our family." When we asked about the potential of prayer, he looked dubious and laughed. "Maybe," he said, "But they say it is according to your faith [geno] and if it's your faith that makes you get healed ..." He looked serious and trailed off. "I don't have faith." 


\section{Belief and moral authority}

For Lucy, Proscovia, and Leo, hope in effective solutions to suffering is often tinged with uncertainty, conditionality, and ambiguity. Each is bound to act within a moral network of relations: one might consider the wishes of a spouse, another a promise made to an elder family member, or another to a church community.

Despite variabilities in geography, family life, and circumstance, contemporary Acholi cosmology is grounded in the notion that "belief" emerges not only in response to experience, but that the practice of belief shapes lived reality. This is regularly articulated by Acholi. For instance, we were reminded repeatedly by Acholi Christians: Jesus states that, "Your faith has healed you." Our interlocutors' words, no matter their "religious" affiliation, recognize the inextricable connections between belief and healing. One middle-aged Acholi man asserted that belief in the efficacy of tic Acholi was a prerequisite for its ability to restore cosmological order. "There's one thing I've observed," he remarked. "First you have to believe in it. It needs your belief." ${ }^{33}$

To believe or not believe in someone/thing (spirits, Jesus, biomedicine, etc.) and its representative ritual authorities (ajwaki, elders, priests, pastors, physicians, etc.) is an affirmation or challenge of power. A person who remarks: "If you don't believe in it, it will not disturb you," is not necessarily denying the existence of malevolent ajwani, but rather emphasizing how belief (as hope and a spiritual allegiance) can ward against harm. Conversely, in this sense "belief" might not necessarily mean a positive orientation, but a powerful fear. There appears to be little variation in this axiom between more "traditionalist" Acholi thinkers and those deeply influenced by religious institutions. The notion that "reality" is constructed by social facts and lived experience, rather than existing a priori, appears widely shared by our Acholi interlocutors.

This hermeneutical aspect of cosmology means that interpretations of experience are not static, and thus experts of moral and ritual order have much to lose or gain in its shifts. In the case of ajwani, spiritual pollutants and their remedies are not intrinsically connected to violence or war, but have a long social history in northern Uganda and elsewhere. For example, John Middleton, who wrote midcentury about the neighbouring Lugbara tribe, noted that their acts of sacrifice to the dead maintain the ideal pattern of authority in a lineage - ritual renews the social order. ${ }^{34}$ Indeed, if rituals have the power to restore the shared moral order, present circumstances demonstrate that they also have the ability to transform it. As demonstrated in the cases described above, moral restoration and transformation are never fully complete. As a process rather than event, two inter-related dynamics commonly complicate the pursuit of remedy: the practical inability or difficulty in meeting and maintaining spiritual and ritual demands; and contestations over ritual power and responsibility provoked by differing responses to ajwani. We explore these dynamics below.

\section{Meeting and maintaining ritual and spiritual demands}

In Acholi, spirits that interact with people demand care and attention, whether they are chased away for being malevolent or domesticated for practical and ritual purposes. This attention might mean ritual devotion and sacrifice, as in the case of ancestors, it might mean exorcism, worship and prayer, as in the case of Christianity. In either case it might mean meeting long-term material and ritual demands. As the stories of Lucy, Proscovia, Leo, and others demonstrate, these rituals are only one part of the ongoing processes of healing and remedy. The labour of care and sacrifice is not restricted to one-time events (however essential they are) - such as Christian exorcism, tum or spirit chasing (ryemo) rituals - but is rather an ongoing process that requires individual vigilance as well as communal material and moral support. While individual rituals (including prayer) are a powerful 
force in addressing the problem of ajwani, human-spirit interactions are continuous, and are also inextricable from human-human interactions.

One male primary school teacher likened spirits to elders, "They are like some of our elders around. You know? A common problem with old people is that they become like children, very demanding, and totally dependent. Their needs keep increasing: I need tea. I need meat. I need this. I need that." Many of the spirits discussed above are understood by our informants as beings with personalities and wants. They get hungry and thirsty. They like attention and respect. As we observed when ajwaki channeled spirits they greet people and interact with them according to local propriety. They may also be "stubborn." For example, during the night when Lucy's spirits possessed her, they insisted upon certain songs and became cross when the singers began a song that did not meet their approval. They can be capricious and change their minds. As pertaining Lucy, the spirits initially wanted a red hen to be sacrificed, but during the dance they requested a (more rare) black hen instead and her brother took off on a bicycle to find one in the nearby village. Spirits can be reasonable and negotiate sympathetically, or they can be "like stubborn uncles," as a young male relative of Lucy's opined.

A common complaint among those seeking spiritual aid is that the ritual demands of ajwaki are ceaseless and difficult to meet. While some attribute this to the greed or business sense of individual ajwaki themselves, others regard these material difficulties as the nature of human-spirit interactions. Still others recognize a range of trustworthiness and authority among ajwaki, distinguishing between "genuine" ajwaki and fraudulent and greedy imposters. Leaving aside the problem of charlatans, it is widely held that spirits become troublesome when neglected, even dangerous.

Who, then, is responsible for meeting ongoing demands? Typically, paternal or affinal male kin and clan elders have authority and responsibility to organize and fund the ritual care of those afflicted by ajwani. Amongst the larger GUSCO sample, $70 \%$ of respondents reported having participated in at least one organized ritual process, the most common being stepping on an egg (nyono tong gweno) ( $50 \%$ of respondents), Christian prayers of all denominations (18.6\%), and other tic Acholi (30\%). Of those individuals who reported never having experienced cen or any other spiritual affliction, $71 \%$ had undergone some sort of ritual process upon their return. For those who self-reported as suffering from cen at the time of the interviews, $69 \%$ had participated in a ritual process, while $74 \%$ of individuals who had previously suffered from cen (but no longer do) participated in a ritual process. During the decades of war and displacement, and largely continuing to date, the financial and logistical demands of rituals often became insurmountable, eroding the authority of and trust in elders. A common complaint of formerly abducted persons is that elders did not organize any rituals upon their return, "not even prayers." The customary expectation that elders held both the obligation and authority to meet ritual needs was somewhat complicated by the massive influx of NGOs during the war (particularly circa 2005 to 2010), some of whom regularly contributed the livestock and refreshments for mass cleansing rituals. ${ }^{35}$

In the midst of the social changes catalysed by the war economy, mass displacement, and a generation of youth raised in camps, there is even more ambiguity and contestation over who should hold ritual and material responsibilities for addressing ajwani. For Lucy, although her brother organized the rituals necessary to alleviate her spiritual ailment, it was only possible once the foreign film crew agreed to cover expenses. Once the threeday long ritual was over Lucy and her ajwaka realized that Lucy's own tipu (spirit) had mistakenly fled her body along with the unwanted ayweya and cen. By then the film crew had left and her brother insisted he could not afford the ritual to summon it back. Some of our interlocutors maintained that who paid for rituals was inconsequential, 
as long as they were performed, but if the provision of ritual requirements is the responsibility and right of elders, the intervention of foreigners might unwittingly contribute to the usurpation of established authority. The system by which funds can be raised is clearly debilitated by decades of war and poverty, and so elders' authority is equally challenged.

On the other hand, a commonly cited advantage of prayer is that it is cheap, or even free. Christian teaching, as our Acholi informants explained, is that grace is a gift undeserved but freely given. The "sacrifice" (tum) of Jesus is a once-and-for-all price paid to "free believers from the burden of sacrifice." To keep the Satans away, we were told, it is necessary to be vigilant in prayer, to keep the teachings of the church, sometimes to fast (particularly in the case of exorcisms), and to attend worship services regularly. Again, our informants did not experience a kind of one time exorcism, which "delivered" them in finality. Rather, they felt the freedom they enjoyed depended upon continually working out their faith.

Other people experienced the "cost" of prayer as prohibitively high. One informant wanted to organize group prayer to chase away spirits but worried about how she would provide hospitality to participants. In some cases leaders of such gatherings expect donations. For many who might wish to be the focus of such prayer, practical considerations are simply unaffordable. In one instance, a woman suffering from ajwani noted that to be a good Christian she had to cease brewing alcohol, and acceptance by her church is contingent upon abandoning her livelihood. When we visited her, she complained she felt torn by the dilemma between her financial and spiritual wellbeing, with the clergy and fellow churchgoers unsympathetic and unhelpful in her predicament. Another shared how he had enjoyed a long period free from "Satanic" attacks after getting saved, but then he missed one service during a busy agricultural season and the next day an attack re-occurred.

\section{Contesting systems of belief}

The power and authority of spirits and deities, priests and pastors, spirit mediums and diviners and clan elders are contested, and these tensions surface around the treatment of ajwani. A born-again adherent is likely to remark that cen has "no authority" to disturb a church member, and as foreign researchers we have often been told that we need not fear cen because it is uninterested in, or rather has no moral jurisdiction over, non-Acholi persons. Nevertheless, the Pentecostal-Charismatic wish to "break with the past" ${ }^{\prime 36}$ and refute the authority of ancestors, elders, and indigenous spirits is not necessarily easily achieved, and the continued impact of spiritual pollution challenges ritual authority.

Pentecostal Christian Churches and the Charismatic movements within Catholicism and Anglicanism offer evidently attractive spiritual alternative to the more orthodox authority of the Roman Catholic and Anglican communions. Before his abduction, one of our key interlocutors was a Catholic, but his local Pentecostal church had a better reputation for dealing with spiritual attacks. "If you get saved, you'll chase Satan," he said. While he did not explicitly condemn his former Catholicism, it was clear his incorporation into a new faith community not only challenged the authority of cen and Satan in his life but also provided him with a new venue of sociality and belonging. "Church has been given power to chase those dirty things," his pastor said. "If we find that after praying during the Sunday service the cen refuses to leave, we release people to go home and pray for the person alone and then we can organize a special day to pray and fast and if they [the spirits] still don't leave, we go to the paternal home because the root cause must be something at home." He explained how this had happened when the young man first came to church: he had made "the mistake" of engaging an ajwaka who "deceived his home people and placed some herbs there." The church burned the bag, effectively asserting their authority even over the ritual action of kin. 
Similar points are illustrated by Proscovia's situation. Interestingly, she believes cen is partially provoked by the virtues of her Christian life and the challenge her beliefs pose to Satan's power. When she encountered hardship and social rejection, she interpreted this as evidence that she was doing something right. When her house was burned down, she said, "The pastors said it was Satan who doesn't want me to pray." Even her child's poisoning and the house fire were understood as attacks from Satan who does not want her to find belonging and love. She attributes the freedom from spiritual disturbances she currently enjoys to the power of the "blood of Jesus" combined with her belief/faith. In her new church she has many close friends, and these companions have seen her through the most trying moments of reintegration: helping her get a job, a new house, and praying with her every week. They sacrifice their time and food to pray and fast for her "victory" over dirty things.

Elsewhere, scholars have written extensively on how Pentecostal-Charismatic churches emphasize intentional ruptures with the past. ${ }^{37} \mathrm{~A}$ rejection of the mainline Protestant and Catholic enculturation of indigenous practices is necessary to break with personal, communal, and national histories and, in so doing, be born again as modern, prosperous, and independent individuals looking towards the future. Pentecostalism allows for a temporal strategy of poeisis, of recovering the memories of the past in a different form of moral practice. While the aforementioned scholars are cautious about the everyday success of this rupture, the calls for rejection of one's past life are grounded in urgency with socio-political consequences. Van Dijk writes that in Malawi the instantaneousness of the bornagain movement, in comparison to the periods of training and initiation required of catechists in established mission churches, challenges established sociopolitical and sociocultural structures. "Such rejection attacks those positions of (gerontocratic) authority which are believed to be based on secretive pasts, and those cultural traditions which are perceived to be formed through the esoteric." ${ }^{38}$

In Acholi, the gerontocratic authority of elders, rwodi (chiefs), atekere (clan ritual specialists), and ajwaki compete with church authority such as those which Proscovia and other key informants attended (both Pentecostal). However, the allure of "something stronger" than prayer, as some of our (non-Pentecostal) informants referred to the work of powerful ajwaki, is sought by many persons suffering the ill effects of ajwani. "Those ajwaki can help because they can speak to those spirits and find out if they are hungry or what they need," remarked one elderly woman with whom we spoke. ${ }^{39}$ And then there are people, like Leo, "without faith" for whom the avenues for remedy seem few and often ineffective.

\section{Conclusion}

Where life and death have been polluted by violence, wrongdoing, and cosmological transgressions, the pursuit of social and cosmological order is embroiled in the politics of belief and doubt. Acholi cosmology is and ever has been evolving, and thus our observations on the problem of ajwani among ex-LRA can only be as accurate as they relate to ongoing lived realities. Nonetheless, we note that what each case of ajwani has in common is that it begs a communal response: far from affecting only isolated cases of GUSCO returnees, ajwani entangle the lives of entire families, clans, and communities.

The experiences of Lucy and her peers paint an intricate picture of pathways and barriers to remedy - individual and collective - in Acholi today, about the language with which ex-LRA combatants communicate spiritual and social suffering, and about the applicability of certain forms of redress over others. These forms of redress have the ability to uphold or challenge existing ritual and moral authorities in Acholi. Rather than expressing categorical certainty over the names, origins, and characteristics of various spirits and psychological phenomena, our informants expressed ambiguity 
as to how they understand, interpret, and render intelligible their own lived experiences with dirty things. Even if pathologizing can be counterproductive, when an experience was given a name with some sort of linguistic purchase (however fluid), we found our interlocutors better able to act upon and respond to spiritual pollution. We find our interlocutors to be flexibly oriented towards remedy, ritual work, social repair, and the alleviation of suffering, no matter their religious affiliations or lack thereof. Those individuals who find themselves most unaided by available channels of support are those who approach existing structures of spiritual authority with no "belief," while medical and psychological services are found woefully inadequate. For others, their ailment has become an opportunity for transformation, new beginnings and new sources of social support.

Many of these dynamics are of course not unique to the Acholi. Studies of post-war reintegration in other contexts might consider the contested nature of the moral order itself: what sociality is valued? When spiritual suffering is concerned, who is served by the emphasis of one avenue of redress over another? To understand the lived experiences of ex-combatant reintegration, inside Uganda and out, it is essential to not assume cosmological stasis or consensus around spiritual pollution. Scholarly and practical interventions alike would do well to consider the pluralistic and ever-changing ideals of communities within which reintegration and the alleviation of spiritual suffering occur. More broadly, the case of post-conflict Acholi highlights the contingent nature of "belief" as a resource for healing and as a category of lived experience. The practices of belief and doubt are not only a matter of metaphysics or ontology, but of shifts in worldly power.

\section{Notes}

1. Interview by the authors, August 2014, Patiko. To protect the identities of our informants we use pseudonyms, and where extra precaution seemed prudent, we do not include the precise dates.

2. The idea that kindness made people more susceptible to cen was re-occurring in our interactions with informants, as well as in previous research. See Hopwood and Osburn, Sharing the Burden of the Past.

3. See Baines, "The Haunting of Alice"; Baines, "Spirits and Social Reconstruction"; and Baines and Gauvin, "Motherhood and Social Repair."

4. Baines, "Spirits and Social Reconstruction."

5. Jackson, Things as They Are.

6. Scholars have examined the concept of cen and other indigenous Acholi cosmological concepts by way of their applicability to clinical psychological and psychiatric interventions (see, for example, Akello, Richters, and Reis, "Reintegration of Child Soldiers in Northern Uganda"; Annan, Blattman, and Horton, The State of Youth and Youth Protection in Northern Uganda; Betancourt et al., "A Qualitative Health Study Mental Health Problems"; and Harlacher, "Traditional Ways of Coping").

7. Our purpose here is not to evaluate psychosocial interventions in northern Uganda, but to recognize that the concept of trauma is entangled in particular medical, colonial, military, and political histories. See Antze and Lambek, Tense Past; Fassin and Rechtman, The Empire of Trauma; Leys, Trauma: A Genealogy; and Young, The Harmony of Illusions.

8. Annan et al., The State of Female Youth in Northern Uganda, 31.

9. UNOCHA, March 10, 2011.

10. See Akello, "Experiences of Forced Mothers in Northern Uganda"; Baines and Stewart, "I Cannot Accept What I Have Not Done"; Carlson and Mazurana, Forced Marriage Within the LRA; Victor, "Death Does Not Rot"; and Porter, "After Rape."

11. Dolan, Social Torture. 
12. See Branch, "Against Humanitarian Impunity"; Dolan, Social Torture; and Finnström, Living With Bad Surroundings.

13. Cf. Allen and Schomerus, A Hard Homecoming; Annan, Blattman, and Horton, The State of Youth and Youth Protection in Northern Uganda; Annan et al., The State of Female Youth in Northern Uganda; Hopwood et al., With or Without Peace; and Pham, Vinck, and Stover, Abducted.

14. The research team, led by the second author, included: Atingo Jacqueline Owacgiu, Robert Okeny, Atim Dorothy Bongomin, Ocitti James Kilara, Candano Jacob, Wokorach Simon Peter, Atim Barbara, Kwame Victor Ben, Adong Sheila Okech, with support from Tim Allen (the Principle Investigator for the JSRP), Melissa Parker and Anna Macdonald. A sample of 304 individual cases was drawn from some 3,000 detailed personal files of GUSCO's former beneficiaries ( $10 \%$ from each year of return between 1997 and 2008, and 20\% from 2009 to 2013 when fewer people returned from the "bush" to civilian life). The research team located and interviewed $77 \%$ of the sample (65\% male and $35 \%$ female), or 234 cases. At the time of writing they had not yet located the remaining $23 \%$ of the sample.

15. Although in northern Uganda "ritual" is normally used in everyday conversation to mean indigenous tic Acholi, for our purposes we refer to ritual in a broader anthropological sense as a generally proscribed series of performative actions legitimated within a moral community.

16. The research was conducted in accordance with the ethical guidelines and standards of the London School of Economics and Political Science policies on human research, and the first author's research was also approved by the University of Toronto Social Sciences, Humanities and Education Research Ethics Board. Additionally, both authors' research projects have clearance from the Ugandan National Council for Science and Technology.

17. Crazzolara, A Study of the Acooli Language, 199.

18. P'Bitek, Religion of the Central Luo.

19. Finnström, Living With Bad Surroundings, 159.

20. Allen, "Bitter Roots"; Baines, "The Haunting of Alice"; Baines, "Spirits and Social Reconstruction"; Behrend, Alice Lakwena and the Holy Spirits; and Porter, After Rape, 99-100.

21. In contrast, a good death happens at home in the presence of close kin who have nursed the dying person and met his or her needs with appropriate care and filial devotion. Funeral rites and burial occur at the homestead, where the spirit (tipu) is free to rest amongst the living and dead members of the clan. For more on bad deaths related to the war see Baines, Roco Wat I Acoli, 12; Baines, "Spirits and Social Reconstruction," 418; and Finnström, "In and Out of Culture," 250.

22. As O'Byrne points out, this is not the case amongst Acholi in Pajok, South Sudan. Deities, Demons and Outsiders, 32-4.

23. As with each of these, the definitions can hardly be captured in our brief parentheticals. Jok is particularly difficult to reduce to shorthand and is discussed further below. See also Mogensen, "The Resilience of Juok."

24. The " $s$ " in "Satans" may not necessarily indicate plurality but as is the case more generally in the speech of Ugandans, refers to a group of people using the plural of a prominent member's name. For an excellent descriptive analysis of most of these phenomena see O'Byrne, Deities, Demons and Outsiders.

25. P'Bitek, Religion of the Central Luo, 145; Crazzolara, A Study of the Acooli Language, 256; Victor, Abomination; and Porter, After Rape, 100-2.

26. On the problem of "belief," see Asad, Genealogies of Religion; Needham, Belief, Language, and Experience; Pouillon, "Remarks on the Verb 'To Believe'"; and Ruel, "Christians as Believers."

27. Bubandt, The Empty Seashell.

28. Evans-Pritchard, Witchcraft, Oracles, and Magic Among the Azande.

29. Second author's field notes, January 15, 2016, Gulu. 
30. Allen, "Bitter Roots," 249, 260.

31. Porter, After Rape, 102-5.

32. There are both "free" jogi as well as jogi associated with landscape features and specific clan shrines and family lines. A jok may be "inherited" within a family line, the spirit passing from one generation to the next.

33. Interview by the authors, August 2014, Kitgum.

34. Middleton, Lugbara Religion, 266.

35. Porter, "After Rape."

36. Meyer, "Make a Complete Break with the Past."

37. See van Dijk, "Pentecostalism, Cultural Memory and the State"; Engelke, "Past Pentecostalism"; Meyer, "Make a Complete Break with the Past"; and Shaw, "Displacing Violence."

38. Van Dijk, "Pentecostalism, Cultural Memory and the State," 164-5.

39. She comes from a Catholic family though she is not a regular church attender herself, and the second author has been in attendance with her at several different tic Acholi to respond to problems in life in the past ten years.

\section{Acknowledgments}

Chiefly, we wish to thank the men and women in Acholi who graciously welcomed us into their lives and shared their experiences with us. We are further grateful for the assistance of GUSCO staff and the rest of the JSRP research team, especially Atingo Jacqueline Owacgiu and Atim Dorothy who saw us through to the end. We would also like to thank Tim Allen, Julian Hopwood, Michael Lambek, Anna Macdonald, Ryan O'Byrne, Todd Sanders and the anonymous reviewers for their constructive comments and engagement with the text.

\section{Disclosure statement}

No potential conflict of interest was reported by the authors.

\section{Funding}

Funds supporting the research and writing of this article were generously provided by the Justice and Security Research Programme at the London School of Economics and Political Science (LSE), through the United Kingdom's Department for International Development (DFID) [grant contract PO5729]. Letha Victor received additional research support from the Canadian Anthropology Society [Richard F. Salisbury Award], the Social Science and Humanities Research Council of Canada [Doctoral Fellowship], the Wenner-Gren Foundation for Anthropological Research [grant number 8874] and writing support from the H.F. Guggenheim Foundation [Dissertation Fellowship]. During the writing phase Holly Porter was additionally supported by the FWO [PEGASUS]2 Marie Skłodowska-Curie Fellowship with the Institute of Development Policy and Management (University of Antwerp) and the Conflict Research Group (Ghent University).

\section{BIBLIOGRAPHY}

Akello, Grace. (2013). "Experiences of Forced Mothers in Northern Uganda: The Legacy of War" Intervention 11(2): 149-156. 
Akello, Grace, Annemiek Richters \& Ria Reis. (2006). "Reintegration of Former Child Soldiers in Northern Uganda: Coming to Terms with Children's Agency and Accountability" Intervention 4(3): 229-243.

Allen, Tim. (2010). “Bitter Roots: The 'Invention' of Acholi Traditional Justice” In The Lord's Resistance Army: Myth and Reality, edited by Tim Allen and Koen Vlassenroot, 242-261. London: Zed Books.

Allen, Tim \& Mareike Schomerus. (2006). A Hard Homecoming: Lessons Learned from the Reception Center Process in Northern Uganda. Washington, DC: Management Systems International.

Annan, Jeannie, Christopher Blattman, Khristopher Carlson \& Dyan Mazurana. (2008). The State of Female Youth in Northern Uganda: Findings from the Survey of War-Affected Youth (SWAY) Phase II. Medford, MA: Feinstein International Center, Tufts University.

Annan, Jeannie, Christopher Blattman \& Roger Horton. (2006). The State of Youth and Youth Protection in Northern Uganda: Findings from the Survey for War Affected Youth. Kampala: UNICEF.

Antze, Paul \& Michael Lambek, eds. (1996). Tense Past: Cultural Essays in Trauma and Memory. London: Routledge.

Asad, Talal. (1993). Genealogies of Religion: Discipline and Reasons of Power in Christianity and Islam. Baltimore: Johns Hopkins University Press.

Baines, Erin K. (2007). "The Haunting of Alice: Local Approaches to Justice and Reconciliation in Northern Uganda" International Journal of Transitional Justice 1(1): 91-114.

Baines, Erin. (2005). Roco Wat I Acoli. Restoring Relationships in Acholi-Land: Traditional Approaches to Justice and Reconciliation. Vancouver: Liu Institute for Global Issues, University of British Columbia.

Baines, Erin. (2010). "Spirits and Social Reconstruction after Mass Violence: Rethinking Transitional Justice" African Affairs 109(436): 409-430.

Baines, Erin \& Lara Rosenoff Gauvin. (2014). "Motherhood and Social Repair after War and Displacement in Northern Uganda" Journal of Refugee Studies 27(2): 282-299.

Baines, Erin \& Beth Stewart. (2011). “I Cannot Accept What I Have Not Done': Storytelling, Gender and Transitional Justice" Journal of Human Rights Practice 3(3): 1-19.

Behrend, Heike. Alice (1999). Lakwena and the Holy Spirits: War in Northern Uganda, 1985-97. Kampala: Fountain.

Betancourt, Theresa Stichick, Liesbeth Speelman, Grace Onyango \& Paul Bolton. (2009). “A Qualitative Study of Mental Health Problems among Children Displaced by War in Northern Uganda" Transcultural Psychiatry 46(2) 238-256.

Branch, Adam. (2008). "Against Humanitarian Impunity: Rethinking Responsibility for Displacement and Disaster in Northern Uganda" Journal of Intervention and Statebuilding 2(2): 151-173.

Bubandt, Nils. (2014). The Empty Seashell: Witchcraft and Doubt on an Indonesian Island. Ithaca: Cornell University Press.

Carlson, Khristopher \& Dyan Mazurana. (2008). Forced Marriage Within the Lord's Resistance Army, Uganda. Medford, MA: Feinstein International Center, Tufts University. 
Crazzolara, Joseph Pasquale. (1938). A Study of the Acooli Language: Grammar and Vocabulary. London: Oxford University Press.

van Dijk, Rijk. (1998). "Pentecostalism, Cultural Memory and the State: Contested Representations of Time in Postcolonial Malawi" In Memory and the Postcolony: African Anthropology and the Critique of Power, edited by Rijk van Dijk \& Richard Werbner, 155-181. London: Zed Books.

Dolan, Chris. (2009). Social Torture: The Case of Northern Uganda, 1986-2006. New York: Berghahn Books.

Engelke, Matthew. (2010). “Past Pentecostalism: Notes on Rupture, Realignment, and Everyday Life in Pentecostal and African Independent Churches" Africa 80(2): 177-199.

Evans-Pritchard, Edward Evan. (1982). Witchcraft, Oracles and Magic among the Azande. 1937. Reprint, Oxford: Clarendon Press.

Fassin, Didier \& Richard Rechtman. (2009). The Empire of Trauma: An Inquiry into the Condition of Victimhood. Princeton: Princeton University Press.

Finnström, Sverker. (2001) "In and Out of Culture: Fieldwork in War-Torn Uganda." Critique of Anthropology 21(3): 247-258.

Finnström, Sverker. (2008). Living with Bad Surroundings: War, History, and Everyday Moments in Northern Uganda. Durham: Duke University Press.

Harlacher, Thomas. (2009) "Traditional Ways of Coping with Consequences of Traumatic Stress in Acholiland: Northern Ugandan Ethnography from a Western Psychological Perspective" PhD diss., University of Freiburg.

Hopwood, Julian \& Chessa Osburn. (2008). Sharing the Burden of the Past: Peer Support and Self Help Amongst Former Lord's Resistance Army Youth. Gulu: The Justice and Reconciliation Project, Quaker Peace and Social Witness.

Hopwood, Julian, Chessa Osburn, Letha Victor \& Erin Baines. (2008). With or Without Peace:

Disarmament, Demobilisation and Reintegration in Northern Uganda. (The Justice and Reconciliation Project Field Notes, no. 6.) Gulu: Gulu District NGO Forum, the Liu Institute for Global Issues, and Quaker Peace and Social Witness.

Jackson, Michael. (1996). Things as They Are: New Directions in Phenomenological Anthropology. Bloomington: Indiana University Press.

Leys, Ruth. (2010). Trauma: A Genealogy. Chicago: University of Chicago Press.

Meyer, Birgit. (1998). "'Make a Complete Break with the Past.' Memory and Post-Colonial Modernity in Ghanaian Pentecostalist Discourse" Journal of Religion in Africa 28(3): 316-349.

Middleton, John. (1999). Lugbara Religion: Ritual and Authority among an East African People. 1960. Reprint, Oxford: James Currey.

Mogensen, Hanne. (2002). "The Resilience of Juok: Confronting Suffering in Eastern Uganda" Africa 72(3): 420-436.

Needham, Rodney. (1972). Belief, Language, and Experience. Oxford: Blackwell. 
O'Byrne, Ryan. (2015). Deities, Demons and Outsiders: The Cosmological Dimensions of (In)security and (In)justice in Pajok, South Sudan. (Justice and Security Research Programme Paper no. 21.) London: Justice and Security Research Programme.

p'Bitek, Okot. Religion of the Central Luo. (1971). Nairobi: East African Literature Bureau.

Pham, Phuong, Patrick Vinck \& Eric Stover. (2007). Abducted: The Lord's Resistance Army and Forced Conscription in Northern Uganda. Berkeley: Berkeley-Tulane Initiative on Vulnerable Populations.

Porter, Holly. (2015). "After Rape: Comparing Civilian and Combatant Perpetrated Crime in Northern Uganda" Women's Studies International Forum 51: 81-90.

Porter, Holly. (2016). After Rape: Violence, Justice and Social Harmony in Uganda. Cambridge: Cambridge University Press.

Pouillon, Jean. (1982). "Remarks on the Verb 'To Believe'" In Between Belief and Transgression: Structuralist Essays in Religion, History and Myth, edited by Michel Izard \& Pierre Smith and translated by John Leavitt, 9-23. Chicago: Chicago University Press.

Ruel, Malcolm. (1997). “Christians as Believers" In Belief, Ritual and the Securing of Life: Reflexive Essays on a Bantu Religion. 1982. Reprint, Leiden: E.J. Brill.

Shaw, Rosalind. (2007). “Displacing Violence: Making Pentecostal Memory in Postwar Sierra Leone” Cultural Anthropology 22(1): 66-93.

Victor, Letha. (2007). "Abomination": Local Belief Systems and International Justice. (Justice and Reconciliation Project, Field Notes, no. 5.) Gulu: Gulu District NGO Forum and the Liu Institute for Global Issues.

Victor, Letha. (2011). "Death Does Not Rot: Women of the Lord's Resistance Army" MA thesis, McGill University.

Young, Allan. (1997). The Harmony of Illusions: Inventing Post-Traumatic Stress Disorder. Princeton: Princeton University Press. 